\title{
Body Image Satisfaction and Interest in Losing Weight between Gender
}

\author{
Marie-Thérèse Khalil* \\ Faculty of Organization Studies Novo mesto, Ulica talcev 3, 8000 Novo mesto, Slovenia \\ Lebanese Canadian University, Aintoura, Lebanon \\ mt.k@live.com
}

Maja Meško

University of Primorska, Faculty of management, 6000 Koper, Slovenia

maja.mesko@gmail.com

\section{Joseph Matta}

Industrial Research Institute, Industrial Research Institute, IRI bldg. - Lebanese University

Campus, Hadath (Baabda), PO Box 11-2806 Beirut, Lebanon

Saint Joseph University, Faculty of Pharmacy, Nutrition Department, Beirut, Lebanon

chem@iri.org.lb

\section{Annmarie Gorenc Zoran}

Faculty of Organisation Studies Novo mesto, Ulica talcev 3, 8000 Novo mesto, Slovenia

a.zoran@fos-unm.si

\author{
Milena Alič \\ ALZIT, d.o.o., Murave 16, 4223 Poljane, Slovenia \\ milena.alic@siol.net
}

\begin{abstract}
:
Purpose and Originality: The study aims to examine and compare body image satisfaction with the level of interest in losing weight between gender, considering cognitive behaviours toward food, age, Body Mass Index, work, marital status, and the number of children.

Method: A quantitative meta-analysis conducted randomly on a pool of Lebanese adults $(\mathrm{n}=514)$ between February 2018 and June 2018. Anthropometric measures and specific demographic data assessed individually, and questions related to the level of body image satisfaction and the level of interest in losing weight were analyzed using bivariate statistical tests (t-test, $\chi 2$ ).

Results: No relationship was found between body image satisfaction and gender at any age $(p>$ $0.05)$, even though women showed a higher mean in the level of interest in losing weight $(2.21 \pm$ $0.835)$ than men $(1.87 \pm 0.835)$. Body image satisfaction was found inversely associated with Body Mass Index and with more significance than the level of interest in losing weight $(p<$
\end{abstract}


0.001). Cognitive behaviours toward food and work status were only found significantly related to body image satisfaction, whereas marital status was solitary found related to the level of interest in losing weight with a small effect size $(p<0.01)$.

Society: This study reflects the different attitude between gender toward body image satisfaction and interest in losing weight in the Lebanese adult population, in order to interpret a better understanding toward image satisfaction, while identifying determinants that might be applied for designing interventions independent of the setting.

Limitations: Pregnant and lactating women were not considered in the sample.

Originality/value: The impact of the study concerns the Lebanese society, and it is the first of its kind to open the subject concerning BIS between different Lebanese social groups and initiate further research in this field.

Keywords: Body Image, Weight Loss, Satisfaction, Age, Gender, BMI, Cognitive Behaviours.

\section{Introduction}

In the context of changes in the ideal body image satisfaction (BIS) perception and its direct and indirect impact especially concerning weight loss therapy, two main research questions (RQ) were examined in this research study:

RQ1. What are the variables among the selected ones that interfere with body image satisfaction (BIS)?

RQ2. Are they consistent with the level of interest in losing weight (ILW)?

This research study consists of measuring the level of BIS between Lebanese adults and comparing it between the different variables of the population, taking into consideration respondents' gender, age, job, marital status, and the number of children. The same comparison was conducted with ILW instead of BIS to check for any differences and possible correlation and association, especially between gender.

The aim of the study is to show that BIS may be better interpreted when substituted with ILW. The investigation is carried out through selective ordinal variables compared between men and women.

\section{Theoretical framework}

Earlier studies found that people tended to underestimate their current weight and overestimate their height (Gorber, Tremblay, Moher, \& Gorber, 2007).

Recent studies indicated correlations between body image satisfaction (BIS) and mental health as well as with physical conditions (Gorber et al., 2007); the reason for which BIS has become an important area of research where the determinants vary by population. Understanding these factors may help to develop targeted strategies to improve BIS when necessary. As such, weight, height and BIS may be influenced by many elements such as physical, interpersonal, emotional, cultural and socioeconomic, including the mass media which increases body image dissatisfaction (BID) and then induce subsequent eating 
disorders (Cash \& Henry, 1995; del Mar Bibiloni, Coll, Pich, Pons, \& Tur, 2017; Erjavec, Štular, \& Kovačič, 2011).

Body image, which is regarded as multidimensional self-attitudes toward one's body, consists of self-perception, cognition, affect, and behaviours vis-a-vis one's physical attributes. Inversely, BID, which is highly prevalent among young women (Tiggemann, 2001), is implicated in a range of public health concerns, including impaired psychological health and weight-related problems such as eating disorders and obesity (M. Bucchianeri \& NeumarkSztainer, 2014).

Many studies have indicated that, in many respects, women possess more negative body image attitudes than men do (del Mar Bibiloni et al., 2017; Grogan, 2016). These differences occur across the lifespan, and the adolescent years may be notably associated with a more negative body image and a tendency for a thinner silhouette (Cash \& Henry, 1995; Collins, 1991; Mooney, Farley, \& Strugnell, 2010). In general, women often want to lose weight, whereas men want to be more muscular at all ages (Grogan, 2016). Women struggle with body image issues throughout their lives, so there is no significant difference in satisfaction between different age groups of women, irrespective of how BIS is measured. However, there are suggestions that media imagery focuses on the importance of youth, but some women do come to terms with their ageing body and report increased self-acceptance with age ( Marshall, Lengyel, \& Menec, 2014). In contrast, older men are likely to be less satisfied with their body size than younger men, though men are likely to have concerns other than weight at all ages, including concerns about insufficient muscularity (Grogan, 2016).

Some other variables concerning eating behaviours, working status as well as being married could be considered. In this context, findings indicated a negative correlation between personal BID and healthy eating habits (Bimbo, Bonanno, Van Trijp, \& Viscecchia, 2018). Alternatively, employed married respondents, with or without children at home, reported the highest levels of emotional well-being. The lowest levels of life satisfaction were reported by the unemployed, students, and divorcees (del Mar Bibiloni et al., 2017; Zuzanek, 1998). In fact, the unemployed population usually perceive themselves as being in poor health (Amstadter et al., 2010; Franzini \& Giannoni, 2010). More specifically, unemployment was also linked to increased health factor risks such as obesity, amongst other habits such as smoking and alcohol and drug consumption (Hollederer, 2011). On the other hand, no relationship was found between marital status and BIS (Alipour, Farhangi, Dehghan, \& Alipour, 2015; Friedman, Dixon, Brownell, Whisman, \& Wilfley, 1999). Nevertheless, married persons without children living at home were more satisfied than married persons with children at home (Glenn \& McLanahan, 1981).

\section{Method}

For this study, a quantitative method was applied using a questionnaire that targeted a pool of random Lebanese adult's $n=514$ (above 19 years of age) of both genders. Participation in the 
survey was anonymous, voluntary, and followed ethical guidelines. Eight registered dietitians conducted individual interviews (one-on-one basis) with the respondents between February 2018 and June 2018. The questionnaire developed for this study consisted of four main parts: (1) demographic (gender, age, work, marital status and number of children); (2) anthropometric (body mass index (BMI)); (3) cognitive behaviours toward food (assessed with a series of three questions based on the six-level Likert scale, from 1 to 6 where 1 is the least flavourful and 6 the most flavourful (self-monitoring of food and calories intake, selected lower calorie foods, and pre-planned meals); and (4) levels of personal body image satisfaction (BIS) and interest in losing weight (ILW) expressed with low, medium, and high.

Based on the theoretical approach that compares the responsiveness of investigated population toward their BIS, each of the ordinal selective variables has a role in checking if the response of the population is dependent and whether it reflects the reality or is attributed to a denial of the truth. In this case this can be tackled through ILW between men and women.

The variables were analysed and presented using univariate statistics, while the comparison between different variables were analysed through bivariate statistics (t-test, $\chi^{2}$ ). The study analysis started with a descriptive statistic method where general characteristics of the collected data from respondents was analysed and evaluated using Microsoft Excel 2016 and Statistical Package for Social Sciences (IBM SPSS statistics version 22). Relationships between different variables comparable with BIS and ILW were measured and statistical significance was assumed when $p<0.05$ and for each significance, the effect size was measured accordingly (Cohen, 1988; Cramer \& Howitt, 2004). The sample consisted of 514 adults randomly selected from one area in the capital of Lebanon. Lactating and pregnant women were excluded from the study.

The process of testing the feasibility of the project proposal, recruitment of subjects, research tool, and data analysis, was reported with a pilot study which was conducted on a group of 50 random Lebanese adults in November 2017. The questionnaire was tested and adjusted based on the answers and feedbacks to provide greater clarity and unambiguous comprehensibility. Based on the preliminary results from the pilot study, according to the demographic structure, respondents were divided equally between men and women. As for the demographic difference between the pilot study and the entire survey, all the variables were nearly similar except for the age ranges which were higher for the young of the entire population compared to the pilot study. To check the internal consistency and reliability of the measuring instrument, Cronbach alpha coefficient was computed for which the demographic variables were excluded. For the entire study, $\alpha=0.756$ and for the pilot study $\alpha=0.715$. Reliability is satisfactory when the coefficient exceeds the recommended value $\alpha=0.7$, which means that the questionnaire, as well as the study, may proceed. 


\section{Results}

600 people were invited to complete the questionnaire, but 86 were either out of the scope (aged less than 19 years, pregnant) or apologized for not participating for personal reasons. Therefore, number 514 represents the sample of Lebanese adults that agreed to carry on with the study; descriptive groups have been detailed in Table 1.

Table 1. Demographic Data of the entire survey $(n=514)$

\begin{tabular}{|c|c|c|c|c|c|c|}
\hline \multirow{2}{*}{$\begin{array}{l}\text { Variables } \\
\text { Gender }\end{array}$} & \multicolumn{6}{|c|}{ Entire study n (\%) } \\
\hline & & & & & & \\
\hline Men & & \multicolumn{5}{|c|}{$224(43.6 \%)$} \\
\hline Women & & \multicolumn{5}{|c|}{$290(56.4 \%)$} \\
\hline \multicolumn{7}{|l|}{ Age } \\
\hline $19-27$ & & \multicolumn{5}{|c|}{$181(35.2 \%)$} \\
\hline $28-36$ & & \multicolumn{5}{|c|}{$119(23.2 \%)$} \\
\hline $37-45$ & & \multicolumn{5}{|c|}{$87(16.9 \%)$} \\
\hline $46-54$ & & \multicolumn{5}{|c|}{$68(13.2 \%)$} \\
\hline$\geq 55$ & & \multicolumn{5}{|c|}{$59(11.5 \%)$} \\
\hline \multicolumn{7}{|l|}{ BMI } \\
\hline Normal-BMI $(\leq 24.9$ kg/m2) & & \multicolumn{5}{|c|}{$261(50.8 \%)$} \\
\hline Over-BMI ( $\geq 25 \mathrm{~kg} / \mathrm{m} 2)$ & & \multicolumn{5}{|c|}{$253(49.2 \%)$} \\
\hline \multicolumn{7}{|l|}{ Work } \\
\hline No & & \multicolumn{5}{|c|}{$136(26.5 \%)$} \\
\hline Part-time & & \multicolumn{5}{|c|}{$65(12.6 \%)$} \\
\hline Full-time & & \multicolumn{5}{|c|}{$313(60.9 \%)$} \\
\hline \multicolumn{7}{|l|}{ Marital Status } \\
\hline Married & & \multicolumn{5}{|c|}{$236(45.9 \%)$} \\
\hline singles living with their parents & & \multicolumn{5}{|c|}{$191(37.2 \%)$} \\
\hline singles (independent) & & \multicolumn{5}{|c|}{$62(12.1 \%)$} \\
\hline Divorced/widowed & & \multicolumn{5}{|c|}{$20(3.9 \%)$} \\
\hline Concubine & & \multicolumn{5}{|c|}{$5(1 \%)$} \\
\hline \multicolumn{7}{|l|}{ Number of children } \\
\hline 0 & & \multicolumn{5}{|c|}{$283(55.1 \%)$} \\
\hline 1 & & & & $8.9 \%)$ & & \\
\hline 2 & & & 98 & $9.1 \%)$ & & \\
\hline 3 & & & & $0.3 \%)$ & & \\
\hline$\geq 4$ & & & & $6.6 \%)$ & & \\
\hline Cognitive behaviour toward food & 1 & 2 & 3 & 4 & 5 & 6 \\
\hline Self-monitoring of food and calories intake & $184(35.8)$ & $59(11.5)$ & $100(19.5)$ & $68(13.2)$ & $47(9.1)$ & $56(10.9)$ \\
\hline Selected lower calorie foods & $187(36.4)$ & $61(11.9)$ & $90(17.5)$ & $67(13)$ & $55(10.7)$ & $54(10.5)$ \\
\hline Planned meals in advance & $194(37.7)$ & $78(15.2)$ & $87(16.9)$ & $58(11.3)$ & $46(8.9)$ & $51(9.9)$ \\
\hline Body Image Satisfaction (BIS) & & & & & & \\
\hline Low & & & 96 & $18.7 \%)$ & & \\
\hline Medium & & & 189 & $36.8 \%)$ & & \\
\hline High & & & 229 & $44.5 \%)$ & & \\
\hline Interest in Losing Weight (ILW) & & & & & & \\
\hline Low & & & 168 & $32.7 \%)$ & & \\
\hline Medium & & & 142 & $27.6 \%)$ & & \\
\hline High & & & 204 & $39.7 \%)$ & & \\
\hline
\end{tabular}


Most of the respondents showed a tendency to favour a positive BIS, which seemed to be similar for both genders, with a total mean of $2.26 \pm 0.753$, whereas the total mean concerning ILW was $2.07 \pm 0.849$ with a better affinity for women who seemed to be more interested in losing weight.

To verify the presence of any relationship between BIS and ILW, a Chi-square test was performed. In this context, a strong significant relationship was detected; $X^{2}(4)=20.442, p<$ 0.001. The effect size for this finding, Cramer's $V$, was moderate: 0.199 . A total of $53 \%$ of participants who showed low ILW had a high BIS, whereas $19.1 \%$ of those with high ILW had a low BIS. To verify whether a relationship was present in BIS between normal and overBMI, a Chi-square test was performed (Figure 1).

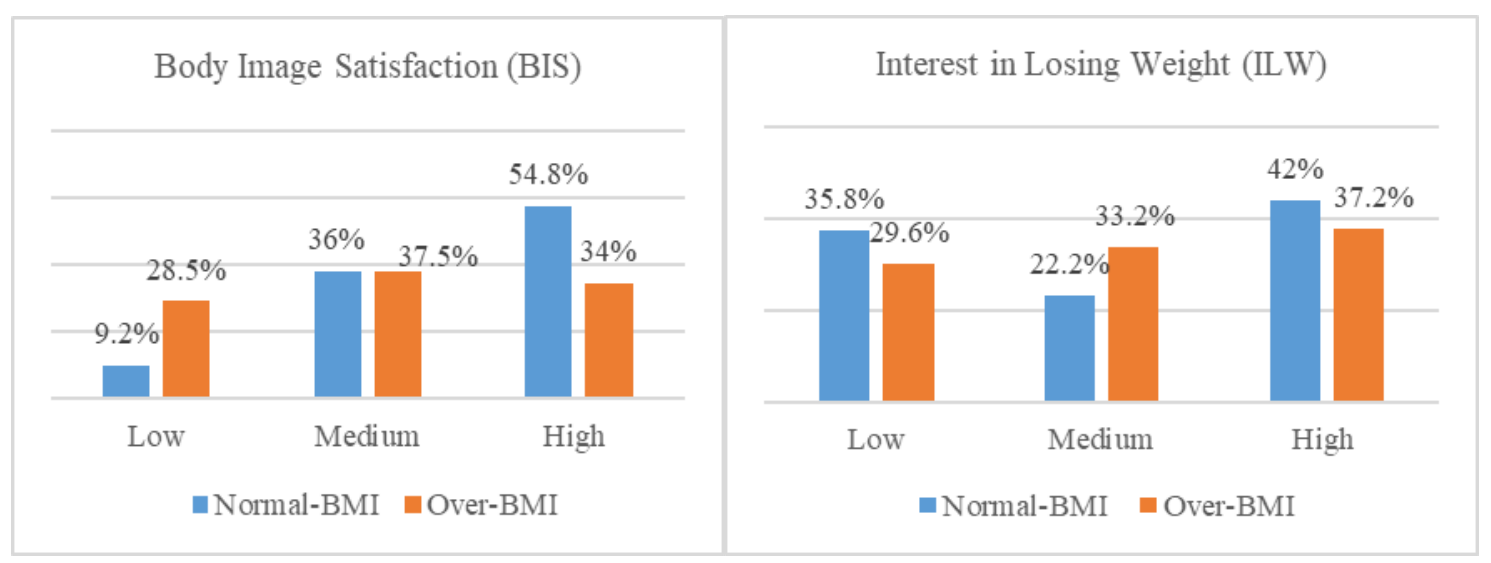

Figure 1. Percentage of BIS and ILW between Normal-BMI and Over-BMI

In this context, BIS between normal-BMI and over-BMI, was found statistically significant: $X^{2}(2)=38.078, p<0.001$. The effect size for this finding, Cramer's $V$, was moderate: 0.272 ; $9.2 \%$ of the respondents with a normal BMI had a low BIS, compared to $28.5 \%$ with overBMI. Most of the respondents with normal-BMI (54.8\%) had a high BIS, compared to only $34 \%$ with an over-BMI. Similarly, ILW between normal and over-BMI was also found statistically significant: $X^{2}(2)=7.821, p=0.020$. However, the effect size for this finding, Cramer's $V$, was small at $0.123 ; 35.8 \%$ of the respondents with normal-BMI showed low ILW, compared to only $29.6 \%$ of those with an over-BMI. Most of the respondents with a normal BMI were in the group highly interested in losing weight $(42.1 \%)$, compared to only $37.2 \%$ of the respondents with an over-BMI.

No relationship between gender and BIS was detected $\left(X^{2}(2)=2.077, p=0.354\right)$. However, a relationship was observed between gender and ILW $\left(X^{2}(2)=17.708, p<0.001\right)$. Still, the effect size for this finding, Cramer's $V$, was small: $0.186 ; 47.2 \%$ of the women showed a high ILW, compared to only $29.9 \%$ of men.

BIS, as well as ILW, were compared between gender and age ranges (Figure 2 and Figure 3); When going through the age ranges, both BIS and ILW decreased with ageing with linear regression and negative correlation for women and also for men except for the group having a 
low-BIS. On the other hand, when running Pearson's Chi-square test, no significant relationship was detected between the different groups of BIS and ILW between age groups and gender $(p>0.05)$ except for the group with medium ILW: $X^{2}(2)=11.690, p=0.020$. The effect size for this finding, Cramer's $V$, was moderate: 0.287 ; In this context, participants who only have a medium ILW decreased in percentage when ageing.

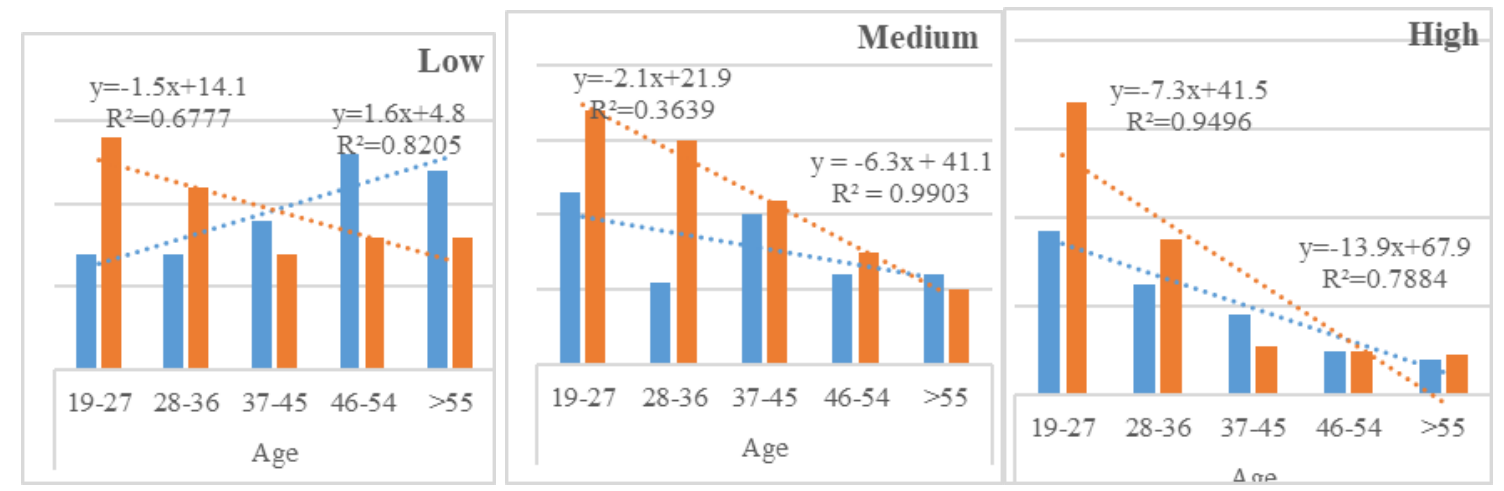

Figure 2. Body image satisfaction (BIS) by age ranges and gender (Blue=Male; Orange=Female)

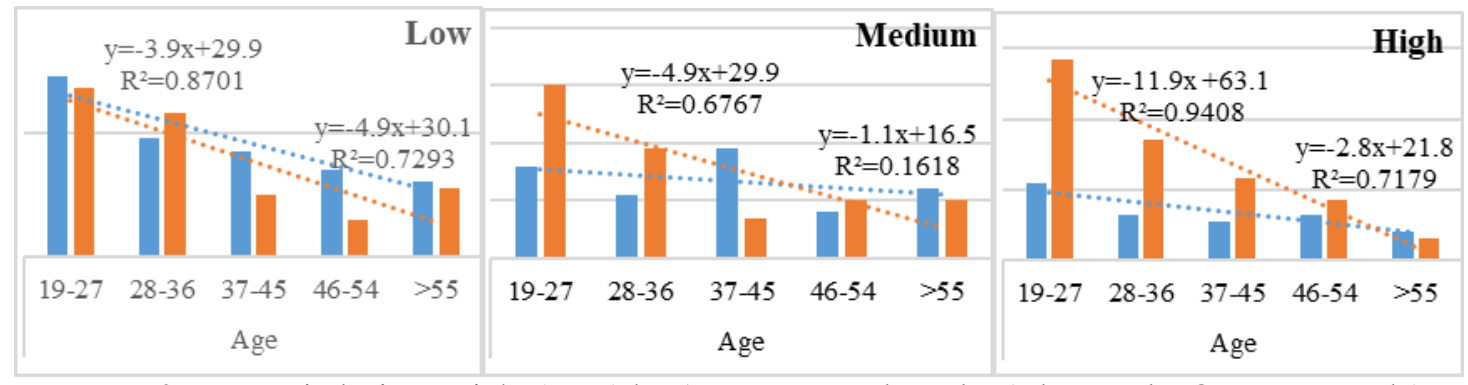

Figure 3. Interest in losing weight (ILW) by Age ranges and gender (Blue=Male; Orange=Female)

In the analysis regarding different behaviours toward food, it was found that most of the respondents do not follow a healthy behaviour toward their food and do not account nor focus on their meals in a vigorous way. When computing each of the three cognitive behaviours toward food with BIS and ILW, a large significant relationship was found between all stated behaviours toward food and BIS as well as with ILW ( $p<0.05$ and Cramer's $V>0.2)$. In this context, when all types of cognitive behaviours toward food increase, both BIS and ILW increase as well. $25 \%$ of participants who never self-monitored their food and calorie intake had a low BIS, whereas $58.9 \%$ of those who had the most self-monitoring had a high BIS. In contrast, $58.3 \%$ of participants who never self-monitored their food and calorie intake had a low ILW, whereas $69.6 \%$ of those who had the most self-monitoring had a high ILW. On the other hand, $22.5 \%$ of participants who never selected lower-calorie food had a low BIS, whereas $63 \%$ of those who mostly selected their calorie intake had a high BIS. In contrast, $52.4 \%$ of participants who never selected lower-calorie food had a low ILW, whereas $74.9 \%$ of those who mostly selected their calorie intake had a high ILW. Similarly, $20.1 \%$ of participants who never planned their meals had a low BIS, whereas $41.6 \%$ of those who mostly planned their meals had a high BIS. In contrast, $47.4 \%$ of participants who never 
planned their meals had a low ILW, whereas $60.8 \%$ of those who mostly planned their meals had a high ILW.

When work status was cross-tabulated between men and women with BIS and ILW, a significant relationship was only found between the sexes for those working part-time regarding BIS with a large effect size. In fact, $27.2 \%$ of part-time working men show a low BIS compared to $2.3 \%$ of women. The majority of women part-time workers have a high BIS compared to men (53.3\% to $36.4 \%$ ). Another significant relationship was also found between the sexes among those working full-time regarding their ILW with a medium effect size, where most of the men (37.7\%) who work full-time have a low ILW, compared to $21.2 \%$ of women. In contrast, the majority of women working full time $(54.8 \%)$ have a high ILW, compared to $31.1 \%$ of men.

On the other hand, when cross-tabulating BIS between genders with marital status, no significant association was found. However, when cross-tabulating ILW with marital status between genders, a significant association with small effect size was found between genders who were not married but lived with their parents and another with a medium effect size between married people; the results showed that the majority of single men living with their parents had a low ILW compared to women ( $43 \%$ to $26.9 \%$ ). Whereas, the majority of single women living with their parents had a high ILW compared to men (46.2\% to $29.2 \%$ ). Likewise, it was also found that the majority of married men had a low ILW compared to women (38.7\% to $24.8 \%$, respectively). Whereas, the majority of married women had a high ILW compared to men (55.2\% to $29.7 \%)$.

When cross-tabulating BIS with the number of children between genders, no significant relationship was found. Whereas, when computing ILW instead of BIS, a significant relationship with a small effect size was found between gender among those who have no children, and another with large effect size was found between gender among those who have two children; the results were as such $42.6 \%$ of men who had no children had a low ILW compared to $28.6 \%$ of women. Conversely, $41.7 \%$ of women who had no children had a high ILW, compared to $30.4 \%$ of men. Alternatively, $44.2 \%$ of men who had two children had a low ILW compared to $20 \%$ of women. Conversely, $60 \%$ of women who had two children had a high ILW compared to $25.6 \%$ of men.

\section{Discussion}

The respondents, in general, showed a relatively high level of body image satisfaction (BIS), which was found inversely associated with BMI and more practically significant than the question related to the level of interest in losing weight (ILW). Alternatively, no significant association was observed with BIS between men and women, but only a small practical significance was detected with ILW. When adding age, no significant association was found with BIS between genders but a medium significance with the group showing a medium ILW. Although Grogan's (2016) work on BIS and its difference between genders, implied that 
women showed a remarkable BID compared with men; this study did not provide similar findings. Cognitive behaviour toward food was found moderately significant with BMI and largely with gender, BIS and ILW, where women always showed a high BIS and also high ILW. Other variables were tested for BIS between genders, such as work status between gender, which was not found significantly associated with BIS or ILW, except for part-time and full-time workers. No relationship was detected between marital status and BIS between genders, but a small significance was noticed between ILW and single respondents still living with their parents and a medium significance was also detected between ILW and married participants. The number of children was not associated with BIS between genders, as well as with ILW, except for those having no children with a small significance, and for respondents having two children but this time with a large significance.

This study aimed to review BIS and ILW between men and women by selecting some variables that may imply in the comparison; however the theoretical framework was not found consistent with this study concerning women which were supposed to have a higher BID, but ILW was consistent with other research studies in this regard where women showed more ILW than men did (McKinley, 2017; Tsai, Lv, Xiao, \& Ma, 2016). Other practical variables, such as cognitive behaviours toward food and working status could also be considered. As for the marital status, no significant association with BIS was showed, similar to the theoretical review (Alipour et al., 2015; Friedman et al., 1999). Inconsistent with the theoretical literature, no association was found between BIS and the number of children, but a strong association was detected between ILW and number of children.

This study opens a debate when assessing BIS leading to consider indirect questions that might imply a hidden psychological denial of the respondents toward their self-esteem following the selected determinant.

\section{Conclusion}

The questionnaire was distributed to adults living in Lebanon, and as such, the results might show a uniformed pattern reflecting a costumed culture in the context of the topic being covered. The data that were collected from Lebanese adult individuals reflects the degree of body image satisfaction (BIS) on the one hand and their level of interest in losing weight (ILW) on the other hand, taking into consideration different variables such as cognitive behaviour toward food, age, gender, BMI, civil status, number of children, and work status. Although women showed more ILW than men, there seems to be no significant difference between both genders when it comes to BIS. Younger women had more BIS, especially the ones with normal BMI. In general, there was a strong negative correlation between BIS and BMI as well as between BIS and age between gender. A strong association was detected between men and women working part-time and BIS. Whereas, medium to high significant association was found between ILW from one hand and married men and women with children and working full-time from another hand. 
ILW should have inversely similar answers to BIS, namely because people who want to lose weight should be unsatisfied with their body image; this was not revealed when computing the listed variables between gender. Suggesting that certain respondents may pretend to be satisfied with their self-image and do not show or tell openly even if anonymously,

As for BMI, there seems to be a rational pattern of answers only with BIS, where most respondents who were over-BMI had a low BIS and vice versa. Instead, when analysing the answers related to ILW, no balanced pattern was shown. In fact, the majority of the respondents wanted to lose weight, whether their BMI was normal or high, which indicates that even respondents with normal-BMI were not satisfied with their body image even though their answers were contradictory.

The questionnaire which was conducted for this study was not benchmarked or compared with any other similar studies. The participants were randomly chosen from common areas; therefore, the findings reflect a mutual culture and a unified society at the regional level. Only adults above 19 years old were considered in this study, and some categories, such as pregnant and lactating women, were out of scope. Finally, the research did not question the media effect nor the impact of physical activity on BIS.

Further research should include the limitations listed above. Also, including other cultures and regions to conduct a comparative analysis with the results of this study. The research is based on BMI, which can be misleading when muscular content is considered compared with fat deposit and body shape type. Many external variables have positive or negative impacts depending on the situation; therefore, there should be a continuous measurement to provide a better, more accurate view of the situation. In this context, further research adding physical activity and media exposure, as well as body shape, should be considered. In the end, a benchmark with other similar Mediterranean cultures should be measured for further studies.

There is no financial interest or risk; No funding source was provided for this manuscript.

\section{References}

1. Alipour, B., Farhangi, M. A., Dehghan, P., \& Alipour, M. (2015). Body image perception and its association with body mass index and nutrient intakes among female college students aged 18-35 years from Tabriz, Iran. Eating and Weight Disorders-Studies on Anorexia, Bulimia and Obesity, 20(4), 465-471.

2. Amstadter, A. B., Begle, A. M., Cisler, J. M., Hernandez, M. A., Muzzy, W., \& Acierno, R. (2010). Prevalence and correlates of poor self-rated health in the United States: the national elder mistreatment study. The American Journal of Geriatric Psychiatry, 18(7), 615-623.

3. Bimbo, F., Bonanno, A., Van Trijp, H., \& Viscecchia, R. (2018). Body image dissatisfaction and health-enhancing food choices: A pilot study from a sample of Italian yogurt consumers. British Food Journal, 120(12), 2778-2792.

4. Cash, T. F., \& Henry, P. E. (1995). Women's body images: The results of a national survey in the USA. Sex Roles, 33(1-2), 19-28. 
5. Cohen, J. (1988). Statistical power analysis for the behavioural sciences: Hillsdale, NJ: erlbaum.

6. Collins, M. E. (1991). Body figure perceptions and preferences among preadolescent children. International Journal of Eating Disorders, 10(2), 199-208.

7. Cramer, D., \& Howitt, D. L. (2004). The Sage dictionary of statistics: a practical resource for students in the social sciences: Sage.

8. del Mar Bibiloni, M., Coll, J. L., Pich, J., Pons, A., \& Tur, J. A. (2017). Body image satisfaction and weight concerns among a Mediterranean adult population. BMC public health, 17(1), 39.

9. E. Marshall, C., O. Lengyel, C., \& H. Menec, V. (2014). Body image and body work among older women: a review. Ethnicity and Inequalities in Health and Social Care, 7(4), 198-210.

10. Erjavec, K., Štular, K., \& Kovačič, M. (2011). Health product advertising through news in lifestyle magazines. Slovenian Journal of Public Health, 50(3), 153-159.

11. Franzini, L., \& Giannoni, M. (2010). Determinants of health disparities between Italian regions. BMC public health, 10(1), 296.

12. Friedman, M. A., Dixon, A. E., Brownell, K. D., Whisman, M. A., \& Wilfley, D. E. (1999). Marital status, marital satisfaction, and body image dissatisfaction. International Journal of Eating Disorders, 26(1), 81-85.

13. Glenn, N. D., \& McLanahan, S. (1981). The effects of offspring on the psychological wellbeing of older adults. Journal of Marriage and the Family, 409-421.

14. Gorber, S. C., Tremblay, M., Moher, D., \& Gorber, B. (2007). A comparison of direct vs. self-report measures for assessing height, weight and body mass index: a systematic review. Obesity reviews, 8(4), 307-326. doi:10.1111/j.1467-789X.2007.00347.x

15. Grogan, S. (2016). Body image: Understanding body dissatisfaction in men, women and children. UK: Routledge.

16. Hollederer, A. (2011). Unemployment and health in the German population: results from a 2005 microcensus. Journal of Public Health, 19(3), 257-268.

17. M. Bucchianeri, M., \& Neumark-Sztainer, D. (2014). Body dissatisfaction: An overlooked public health concern. Journal of Public Mental Health, 13(2), 64-69.

18. McKinley, N. M. (2017). Ideal weight/ideal women: Society constructs the female Weighty Issues (pp. 97-115). UK: Routledge.

19. Mooney, E., Farley, H., \& Strugnell, C. J. (2010). Body dissatisfaction and dieting among adolescent females in the Republic of Ireland (ROI) A quantitative study. Nutrition \& Food Science, 40(2), 176-185.

20. Tiggemann, M. (2001). Person $\times$ situation interactions in body dissatisfaction. International Journal of Eating Disorders, 29(1), 65-70.

21. Tsai, S. A., Lv, N., Xiao, L., \& Ma, J. (2016). Gender differences in weight-related attitudes and behaviors among overweight and obese adults in the United States. American journal of men's health, 10(5), 389-398.

22. Zuzanek, J. (1998). Time use, time pressure, personal stress, mental health, and life satisfaction from a life cycle perspective. Journal of Occupational Science, 5(1), 26-39. 


\section{APPENDICES}

Appendix: Questionnaire
1- Gender:
$\square$ Male
$\square$ Female

2- Age:

$\square$ 19-27

$\square 28-36$

$\square 37-45$

$\square 46-54$

$\square \geq 55$

3- Work (العمل):

$\square$ No

$\square$ Part-Time

$\square$ Full-Time

4- Civil Status:

$\square$ Independent single

$\square$ Single with parents $\square$ Married

$\square$ Divorce/widow

$\square$ Concubine

5- Number of children:
$\square 0$
$\square 1$
$\square 2$
$\square 3$
$\square \geq 4$

6- BMI:

$\square$ Normal-BMI $(\leq 24.9 \mathrm{~kg} / \mathrm{m} 2)$

$\square$ Over-BMI $(\geq 25 \mathrm{~kg} / \mathrm{m} 2)$

7- Your Behaviour toward eating (from 1 to 6 ) where 1 is never and 6 is always

\begin{tabular}{lllllll}
\hline $1(-)$ & 2 & 3 & 4 & 5 & $6(+)$ \\
\hline
\end{tabular}

7.1 Self-monitoring of food and calorie intake

7.2 Selected lower calorie foods

7.3 Planned healthy meals in advance

\begin{tabular}{lllll}
\hline & & Low & Medium & High \\
\hline 8- & Self-image satisfaction & & & \\
9- & Interest in losing weight & & & \\
\hline
\end{tabular}


Marie-Thérèse Khalil is a Registered Dietician who lives currently in Beirut, Lebanon and works as a quality specialist in the Quality unit at the Ministry of Economy and Trade in Lebanon and as a teacher of agro food industry and quality and food service management in the Lebanese Canadian university, faculty of arts and science. Marie-Thérèse is a member of EFQM assessors and has several writings in the domain of dietetics, microbiology, supplements and sports nutrition in local magazines and newspapers. She holds a PhD of Science in the field of Quality Management from the faculty of organisation studies in Novo mesto, Slovenia. She also holds a BS in Biochemistry and a MS degree in Nutrition and food service management from the Lebanese University.

$* * *$

Maja Meško is a full professor of management at the Faculty of Management, University of Primorska. She received $\mathrm{PhD}$ in kinesiology, the title of her doctoral dissertation is Defining certain motor abilities and psychological characteristics of the Slovenian military pilots. Her research interests include the areas of management, psychology in management, occupational health and management. She has also participated in various projects. She authored or co-authored various scientific papers published in professional and academic journals.

Joseph Matta is the head of the laboratories of the Industrial Research Institute (IRI). He provided scientific interaction between universities and industries at the local and international level to ensure multiple projects and research. He published more than 50 articles and new international analytical food tests methods validation. He is a member of several scientific committees, and at the international level, he is the President of the Technical Committee of the Scientific Association of Reference Laboratories "European Federation of National Associations of Measurement, Testing and Analytical Laboratories." In addition, he is a lead auditor of the Food Safety Management Systems ISO 22000 and the competence of the analysis and testing laboratories ISO 17025, member of Technical Committees of the International Organization for Standardization (ISO) and Member of the Scientific Committee of accreditation of laboratories. Professor Matta received the first prize of technological innovation of the EU in 2013.

Annmarie Gorenc Zoran is a Professor at the Faculty of Organisation Studies in Novo mesto, as well as teaches distance learning courses abroad. Her research interest is an interdisciplinary approach to communication as a channel in elearning, framework for continuous improvement (quality standards feedback), a tool in education/teaching, an analytical framework to research, and as a contribution to management. She has published book chapters, numerous articles, and presented at international, national, and regional conferences.

$* * *$

Milena Alič studied maths, IT and management (on master and doctoral degree). She is a manager of her own company and Assistant Professor at the Faculty of Economics, University of Ljubljana, Slovenia. She is working on quality management, IT and environmental topics as practitioner (expert, auditor, consultant, trainer), researcher, author, reviewer at renowned scientific journals (e.g. TQM\&BE - SSCI indexed) and member of different organizations on national and international level (e.g. official representative of Slovenia at EOQ).

$* * *$

\section{Povzetek: \\ Zadovoljstvo in zanimanje za izgubo teže med spoloma}

Namen in izvirnost: Cilj študije je preučiti in primerjati zadovoljstvo telesne slike s stopnjo zanimanja za izgubo teže med spolom, upoštevajoč kognitivno vedenje do hrane, starosti, indeksa telesne mase, dela, zakonskega stanja in števila otrok.

Metoda: Kvantitativna metaanaliza, izvedena naključno na bazenu libanonskih odraslih $(\mathrm{n}=514)$ med februarjem 2018 in junijem 2018. Antropometrični ukrepi in posebni demografski podatki se ocenjujejo posamično ter vprašanja $\mathrm{v}$ zvezi s stopnjo zadovoljstva $\mathrm{s}$ telesno sliko in stopnjo zanimanje za izgubo teže smo analizirali s pomočjo bivarijantnih statističnih testov (t-test, $\chi 2$ ). 
Rezultati: Ni bilo ugotovljeno razmerje med zadovoljstvom s telesno sliko in spolom v kateri koli starosti ( $p>0,05)$, čeprav so ženske pokazale višji povprečni nivo zanimanja za izgubo teže $(2,21 \pm$ $0,835)$ kot moški $(1,87 \pm 0,835)$. Ugotovljeno je bilo, da je zadovoljstvo telesne slike obratno povezano $\mathrm{z}$ indeksom telesne mase in bolj pomembno kot stopnja zanimanja za izgubo teže ( $\mathrm{p}$ $<0,001)$. Kognitivno vedenje do hrane in delovnega stanja je bilo le pomembno povezano $\mathrm{z}$ zadovoljstvom s telesno sliko, medtem ko je bil zakonski status samoten, povezan s stopnjo zanimanja za izgubo teže $\mathrm{z}$ majhnim učinkom $(\mathrm{p}<0,01)$.

Družba: Ta študija odraža različen odnos med spolom do zadovoljstva s telesno sliko in zanimanje za izgubo teže libanonske odrasle populacije, da bi razlagali boljše razumevanje zadovoljstva slike, hkrati pa opredelili dejavnike, ki bi se lahko uporabili za načrtovanje intervencij neodvisno od nastavitve .

Omejitve: V vzorcu niso bile upoštevane nosečnice in doječe ženske.

Izvirnost / vrednost: Vpliv študije zadeva libanonsko družbo in je prva takšna vrsta, ki bo odprla temo BIS med različnimi libanonskimi družbenimi skupinami in začela nadaljnje raziskave na tem področju.

Ključne besede: telesna slika, izguba teže, zadovoljstvo, starost, spol, BMI, kognitivno vedenje.

Copyright (c) 2020 Marie-Thérèse KHALIL, Maja MEŠKO, Joseph MATTA, Annmarie GORENC ZORAN, Milena ALIČ

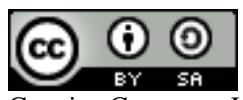

Creative Commons License

This work is licensed under a Creative Commons Attribution-ShareAlike 4.0 International License. 